\title{
Tuning the Hydrophobicity of Zinc Dipyridyl Paddlewheel Metal- Organic Frameworks for Selective Sorption
}

\author{
Mitchell H. Weston, Amelia A. Delaquil, Amy A. Sarjeant, Omar K. Farha,* Joseph T. Hupp,* \\ and SonBinh T. Nguyen*
}

Department of Chemistry and the International Institute for Nanotechnology, Northwestern University, 2145 Sheridan Road, Evanston, Illinois 60208-3113, United States

Supporting Information

ABSTRACT: A series of isostructural noncatenated, water-stable zinc-based dipyridyl pillared-paddlewheel metal-organic frameworks (MOFs) was synthesized with tunable pore hydrophobicity. Pore hydrophobicity was engendered through dipyridyl ligands decorated with alkyl chains of varying length (methyl to hexyl). The most hydrophobic MOFs exhibited selective sorption of ethanol over water.

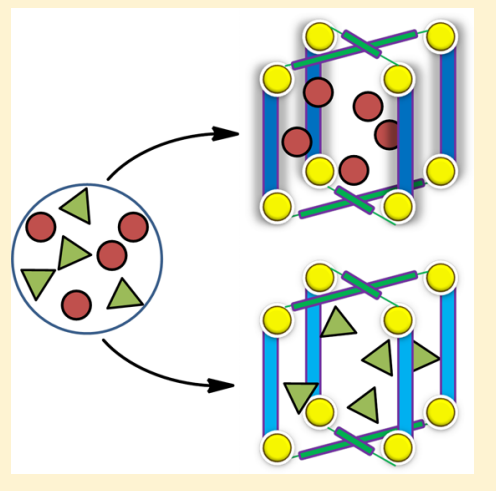

\section{INTRODUCTION}

Since their inception, metal-organic frameworks (MOFs) have been recognized as promising candidates for a wide range of applications such as gas storage, ${ }^{1-8}$ separations, ${ }^{9-12}$ catalysis, ${ }^{13-18}$ sensing, ${ }^{19,20}$ and light harvesting. ${ }^{21-25}$ The extensive interest in MOFs for these applications stems in part from their highly desirable combination of permanent porosity and tailorability. ${ }^{26}$ By employing a particular combination of building blocks from the myriad of available organic ligands and metal nodes, MOFs with a wide range of structures and micropore environments can be designed and tuned for many applications of interest. Despite the large selection of available MOFs, many current MOFs of interest suffer from instability upon prolonged exposure to water, ${ }^{27,28}$ which precludes their use in processes where water is a significant component. Herein, we report a systematic attempt to tune the hydrophobicity of the pore environment within a series of isostructural water-stable zinc-cornered pillared-paddlewheel MOFs by varying the length of appended alkyl chains on one of the two struts. The resulting materials were found to have selective sorption properties against water and preference for a series of hydrocarbon solvents depending on the appended alkyl chain length.

\section{EXPERIMENTAL SECTION}

Representative procedure for the synthesis of $\mathbf{L 1}(\mathbf{a}-\mathbf{f})$ (see Scheme S1 in the Supporting Information (SI)).

4,4'-(2,3,5,6-Tetramethoxy-1,4-phenylene)dipyridine (L1a). 1,4-Dibromo-2,3,5,6-tetramethoxy benzene (S1a) (505 mg, 1.23 $\mathrm{mmol}$ ), pyridin-4-ylboronic acid (445 $\mathrm{mg}, 3.62 \mathrm{mmol}$ ), palladium acetate $(11 \mathrm{mg}, 0.05 \mathrm{mmol}), \mathrm{LiOH} \cdot \mathrm{H}_{2} \mathrm{O}(167 \mathrm{mg}, 4.0 \mathrm{mmol})$, 2- dicyclohexylphosphino-2',6'-dimethoxybiphenyl (40 mg, $0.10 \mathrm{mmol}$ ), 1,4-dioxane $(12 \mathrm{~mL})$, and water $(6 \mathrm{~mL})$ were combined in a microwave vial $(20 \mathrm{~mL}$, capacity designates the amount of solution that can be safely loaded) equipped with a magnetic stir bar. The resulting mixture was degassed for $30 \mathrm{~min}$ by a bubbling stream of $\mathrm{N}_{2}$. The vial was then capped and heated at $100{ }^{\circ} \mathrm{C}$ in a microwave reactor for $6 \mathrm{~h}$. The mixture was cooled to rt, filtered through Celite, concentrated, and purified using column chromatography (25\% ethyl acetate/hexanes to $60 \%$ ethyl acetate/hexanes) to afford L1a as white crystals $(397 \mathrm{mg}, 79 \%)$ after isolation. ${ }^{1} \mathrm{H}$ NMR $\left(500 \mathrm{MHz}, \mathrm{CDCl}_{3}\right): \delta$ $=8.68(\mathrm{~d}, J=5.8 \mathrm{~Hz}, 4 \mathrm{H}), 7.38(\mathrm{~d}, J=5.8 \mathrm{~Hz}, 4 \mathrm{H}), 3.59(\mathrm{~s}, 12 \mathrm{H})$ ppm. ${ }^{13} \mathrm{C}$ NMR $\left(125 \mathrm{MHz}, \mathrm{CDCl}_{3}\right): \delta=149.3,147.0,142.1,128.6$, 125.5, 61.1. ESI-MS: calcd. for $\mathrm{C}_{20} \mathrm{H}_{20} \mathrm{~N}_{2} \mathrm{O}_{4}$ 352.14; found 352.14 .

4,4'-(2,3,5,6-Tetraethoxy-1,4-phenylene)dipyridine (L1b). ${ }^{1} \mathrm{H}$ NMR (500 MHz, $\left.\mathrm{CDCl}_{3}\right): \delta 8.67(\mathrm{~d}, J=5.6 \mathrm{~Hz}, 4 \mathrm{H}), 7.41(\mathrm{~d}, J=5.9$ $\mathrm{Hz}, 4 \mathrm{H}), 3.78(\mathrm{q}, J=7.0 \mathrm{~Hz}, 8 \mathrm{H}), 1.06(\mathrm{t}, J=7.0 \mathrm{~Hz}, 12 \mathrm{H}) .{ }^{13} \mathrm{C} \mathrm{NMR}$ $\left(125 \mathrm{MHz}, \mathrm{CDCl}_{3}\right): \delta=149.2,146.2,142.5,129.0,125.7,69.6,15.6$. ESI-MS: calcd. for $\mathrm{C}_{24} \mathrm{H}_{28} \mathrm{~N}_{2} \mathrm{O}_{4} 408.2049$; found 408.205.

4,4'-(2,3,5,6-Tetrapropoxy-1,4-phenylene)dipyridine (L1C). ${ }^{1} \mathrm{H}$ NMR (500 MHz, $\mathrm{CDCl}_{3}$ ): $\delta 8.59(\mathrm{~d}, J=5.2 \mathrm{~Hz}, 4 \mathrm{H}), 7.35$ (d, $J=5.8 \mathrm{~Hz}, 4 \mathrm{H}), 3.60(\mathrm{t}, J=6.6 \mathrm{~Hz}, 8 \mathrm{H}), 1.40-1.32(\mathrm{~m}, 8 \mathrm{H}), 0.64(\mathrm{t}$, $J=7.4 \mathrm{~Hz}, 12 \mathrm{H}) \cdot{ }^{13} \mathrm{C}$ NMR $\left(125 \mathrm{MHz}, \mathrm{CDCl}_{3}\right): \delta=149.1,146.4$, 142.6, 129.1, 126.0, 75.7, 23.4, 10.4. ESI-MS: calcd. for $\mathrm{C}_{28} \mathrm{H}_{36} \mathrm{~N}_{2} \mathrm{O}_{4}$ 464.2675; found 464.268 .

4,4'-(2,3,5,6-Tetrabutoxy-1,4-phenylene)dipyridine (L1d). ${ }^{1} \mathrm{H}$ NMR $\left(500 \mathrm{MHz}, \mathrm{CDCl}_{3}\right): \delta 8.66(\mathrm{~d}, J=5.6 \mathrm{~Hz}, 4 \mathrm{H}), 7.40(\mathrm{~d}$, $J=5.8 \mathrm{~Hz}, 4 \mathrm{H}), 3.69$ (t, $J=6.4 \mathrm{~Hz}, 8 \mathrm{H}), 1.39(\mathrm{dt}, J=14.3,6.5 \mathrm{~Hz}$, $8 \mathrm{H}), 1.18-1.06(\mathrm{~m}, 8 \mathrm{H}), 0.74(\mathrm{t}, J=7.4 \mathrm{~Hz}, 12 \mathrm{H}) .{ }^{13} \mathrm{C}$ NMR $(125$

Received: March 5, 2013

Revised: April 30, 2013

Published: May 3, 2013 
Scheme 1. Synthesis of RO-MOF(a-f) where R = Methyl (RO-MOFa), Ethyl (RO-MOFb), Propyl (RO-MOFc), Butyl (ROMOFd), Pentyl (RO-MOFe), or Hexyl (RO-MOFf)

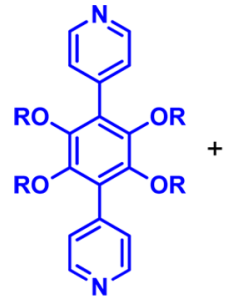

L1(a-f)<smiles>O=C(O)c1ccc(-c2c(Br)c(-c3ccc(C(=O)O)cc3)c(-c3ccc(C(=O)O)cc3)c(Br)c2-c2ccc(C(=O)O)cc2)cc1</smiles>

L2

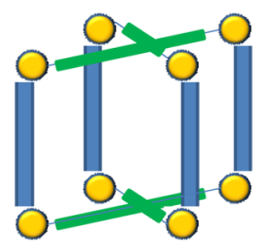

RO-MOF(a-f)
$\left.\mathrm{MHz}, \mathrm{CDCl}_{3}\right): \delta=149.1,146.3,142.4,129.0,125.9,73.6,32.1,18.9$, 13.7. ESI-MS: calcd. for $\mathrm{C}_{32} \mathrm{H}_{44} \mathrm{~N}_{2} \mathrm{O}_{4}$ 520.3301; found 520.330.

4, '4'-(2,3,5,6-Tetrapentoxy-1,4-phenylene)dipyridine (L1e). ${ }^{1} \mathrm{H}$ NMR $\left(500 \mathrm{MHz}, \mathrm{CDCl}_{3}\right): \delta 8.59(\mathrm{~d}, J=5.6 \mathrm{~Hz}, 4 \mathrm{H}), 7.34(\mathrm{~d}$, $J=5.7 \mathrm{~Hz}, 4 \mathrm{H}), 3.62(\mathrm{t}, J=6.5 \mathrm{~Hz}, 8 \mathrm{H}), 1.40-1.29(\mathrm{~m}, 8 \mathrm{H}), 1.11-$ $0.95(\mathrm{~m}, 16 \mathrm{H}), 0.72(\mathrm{t}, J=7.1 \mathrm{~Hz}, 12 \mathrm{H}) .{ }^{13} \mathrm{C}$ NMR $(125 \mathrm{MHz}$, $\left.\mathrm{CDCl}_{3}\right): \delta=149.1,146.4,142.4,129.0,126.0,74.0,29.8,28.0,22.4$, 14.0. ESI-MS: calcd. for $\mathrm{C}_{36} \mathrm{H}_{52} \mathrm{~N}_{2} \mathrm{O}_{4}$ 576.3927; found 576.393.

4,4'-(2,3,5,6-tetrahexoxy-1,4-phenylene)dipyridine (L1f). ${ }^{1} \mathrm{H}$ $\operatorname{NMR}\left(500 \mathrm{MHz}, \mathrm{CDCl}_{3}\right): \delta 8.66(\mathrm{~d}, J=4.9 \mathrm{~Hz}, 4 \mathrm{H}), 7.48(\mathrm{~s}, 4 \mathrm{H})$ $3.69(\mathrm{t}, J=6.4 \mathrm{~Hz}, 8 \mathrm{H}), 1.45-1.37(\mathrm{~m}, 8 \mathrm{H}), 1.25-1.15(\mathrm{~m}, 8 \mathrm{H})$, $1.15-1.05(\mathrm{~m}, 16 \mathrm{H}), 0.83(\mathrm{t}, J=7.2 \mathrm{~Hz}, 12 \mathrm{H}) .{ }^{13} \mathrm{C} \mathrm{NMR}(125 \mathrm{MHz}$ $\left.\mathrm{CDCl}_{3}\right): \delta=148.2,146.5,143.7,129.0,126.4,74.2,31.6,30.1,25.6$, 22.7, 14.2. ESI-MS: calcd. for $\mathrm{C}_{40} \mathrm{H}_{60} \mathrm{~N}_{2} \mathrm{O}_{4}$ 632.4553; found 632.455 .

Representative Synthesis of RO-MOF(a-f). RO-MOFa. Dipyridyl ligand L1a (45 mg, $0.128 \mathrm{mmol}$ ), tetracarboxy ligand $\mathbf{L 2}(62 \mathrm{mg}$, $0.085 \mathrm{mmol})$, and $\mathrm{Zn}\left(\mathrm{NO}_{3}\right)_{2} \cdot 6 \mathrm{H}_{2} \mathrm{O}(51 \mathrm{mg}, 0.17 \mathrm{mmol})$ were suspended in DMF $(18 \mathrm{~mL})$ and untrasonicated until homogeneous. Conc. $\mathrm{HCl}(5 \mu \mathrm{L})$ was added and the solution was mixed and partitioned equally between six 2 dram vials. The vials were then capped and heated in an oven at $80{ }^{\circ} \mathrm{C}$. After 3 days, the vials were removed from the oven and allowed to cool to rt. The mother liquor was decanted from the crystals and replaced with fresh DMF $(5 \mathrm{~mL})$. The vial was capped and kept at ambient lab conditions for two days, over which time the supernatant was decanted and replenished with fresh DMF $(5 \mathrm{~mL})$ four times to remove any extra ligands and nodes. At this point, the TGA profile of the as-synthesized materials was measured and the amount of adsorbed DMF was used to determine crystal yields (35 mg, 34\%).

For activation, the as-synthesized RO-MOF crystals were suspended in fresh THF $(5 \mathrm{~mL})$ and kept at ambient lab conditions for two days, over which time the supernatant was decanted and replenished with fresh THF $(5 \mathrm{~mL})$ four times to remove adsorbed DMF. At the end of the last decantation cycle, the crystals were collected and heated at $80^{\circ} \mathrm{C}$ under high vacuum for $2 \mathrm{~h}$ immediately prior to gas- or vapor-sorption measurements.

\section{RESULTS AND DISCUSSION}

Given our long-standing interests in the synthesis of zinccornered paddlewheel mixed ligand MOFs containing bis(pyridyl) struts with tailorable microporous environments, ${ }^{16,21,29-34}$ we employed this structural motif as a platform for examining the hydrophobicity of pore environments. In particular, we selected dipyridyl ligands L1(a-f), which can be functionalized with various alkyl substituents to a high degree that allows for the hydrophobicity of the MOF micropore environment to be tuned in a systematic and symmetric manner. For the second building block, we select the tetratopic carboxy ligand L2, which has been shown to prohibit catenation. $^{32,33}$

RO-MOF(a-f) are synthesized by combining L1(a-f) and L2 together in the presence of zinc nitrate under solvothermal conditions (Scheme 1). While good single-crystal diffraction data can be obtained for RO-MOFa and RO-MOFc (Figure 1a), full structural data could not be obtained for the others,

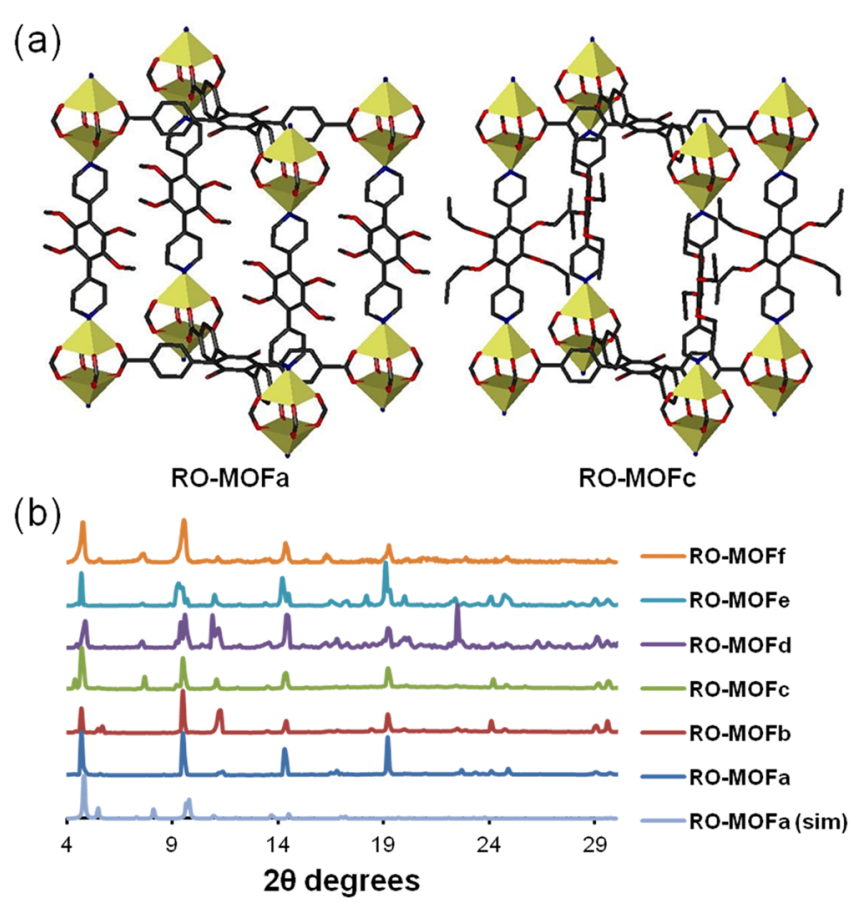

Figure 1. (a) Crystallography-derived stick representations of the unit cells of RO-MOFa and RO-MOFc (yellow polyhedral $=\mathrm{Zn}$, blue $=\mathrm{N}$, red $=\mathrm{O}$, gray $=\mathrm{C}$ ). Hydrogen atoms and disordered solvent molecules have been omitted for clarity. (b) PXRD patterns for RO-MOFa-f and simulated RO-MOFa.

largely due to the distortion caused by the rotation of the alkyl chains. Nonetheless, the available single-crystal diffraction data revealed that all the MOFs have similar unit cell parameters $(a$ $=11 \AA, b=16 \AA, c=18 \AA$ ). The alignment of the PXRD patterns of the RO-MOFs (Figure 1b), as well as the agreement between the bulk experimental PXRD pattern of RO-MOFa and its simulated PXRD pattern, clearly illustrate the isostructural relationship among the members in this series. Further supporting this structural assignment is the observation that samples of $\mathrm{D}_{2} \mathrm{SO}_{4}$-digested RO-MOF(a-f) all possess stoichiometric ratios of their parent ligands, as verified by NMR spectroscopy (see Section S3 in the SI). In the case of ROMOF(c-f), L1(c-f) ligands underwent acid-induced ether cleavage upon exposure to $\mathrm{D}_{2} \mathrm{SO}_{4}$, most likely due to the formation of stable carbocations; however, the remaining pyridyl protons related to ligands $\mathbf{L 1}(\mathbf{c}-\mathbf{f})$ showed stoichiometric agreement with those for L2. 
The hoped-for porosity, as suggested by the large threedimensional noncatenated channels in the crystal structures of the RO-MOF(a-f) materials, was confirmed through TGA measurements (Figure 2), which uniformly revealed $\sim 30-40 \%$

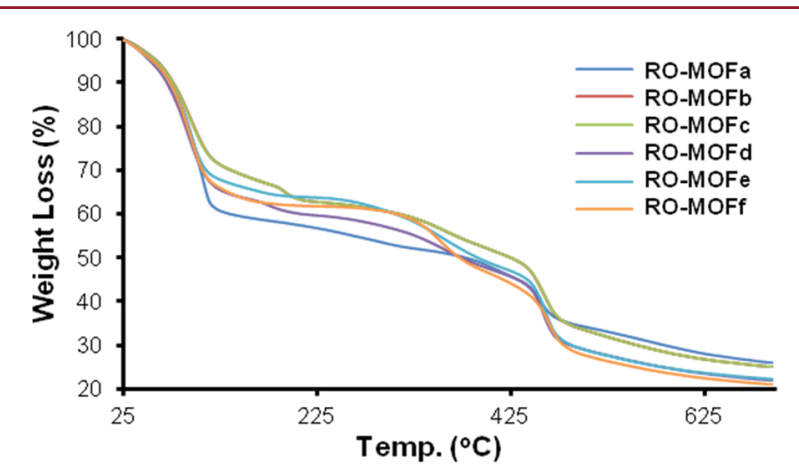

Figure 2. TGA profiles of as-synthesized RO-MOF(a-f).

mass loss at $\sim 110{ }^{\circ} \mathrm{C}$ due to entrapped solvent (DMF). TGA measurements also indicate high stabilities, as all MOFs showed no sign of framework pyrolysis until $>300{ }^{\circ} \mathrm{C}$. Further analysis of the representative framework RO-MOFa reveals that it is stable and can be resolvated after solvent removal (by heating to $80{ }^{\circ} \mathrm{C}$ under dynamic vacuum) with almost no loss of capacity for guest solvents (see Figure S25 in the SI).

After activation, RO-MOF(a-f) all displayed permanent microporosity as shown by gas adsorption $\left(\mathrm{CO}_{2}\right.$ at $273 \mathrm{~K}$, Figure 3). Unfortunately, these RO-MOFs, regardless of

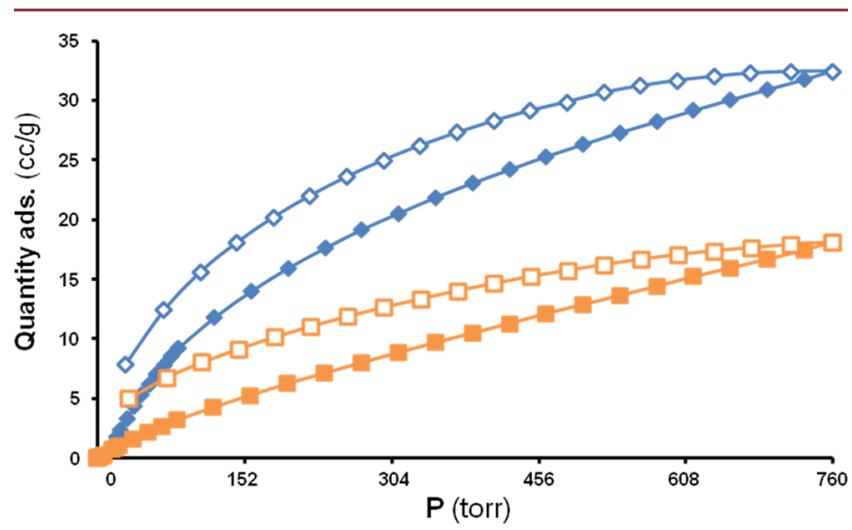

Figure 3. $\mathrm{CO}_{2}$ isotherms measured at $273 \mathrm{~K}$ for RO-MOFa (blue diamonds) and RO-MOFe (orange squares). Closed symbols, adsorption; open symbols, desorption.

activation protocol, failed to uptake nitrogen in appreciable amounts, which limited further sorption analysis such as BETdetermined surface areas or DFT-derived pore size distributions. Although the surface areas of these materials (Table 1; see also Table $S 1$ in the SI) are significantly lower $\left(355 \mathrm{~m}^{2} / \mathrm{g}\right.$ for RO-MOFa) than expected, this is not uncommon for MOFs, specifically zinc-based dipyridyl paddlewheel MOFs. ${ }^{35}$ Such lower-than-expected surface areas has been attributed to either (1) outer shell collapse, ${ }^{36}$ or (2) plate shifting observed in flexible MOFs, ${ }^{19,34,37-39}$ both of which limits the ability of the gas molecules to probe internal pores (Scheme S2 in the SI). An indication of possible flexible plate shifting in the ROMOFs is the significant hysteresis upon $\mathrm{CO}_{2}$ desorption (Figure 3; see also S3 in the SI), which has been observed in other flexible dipyridyl MOFs. ${ }^{40}$
Table 1. Vapor-Sorption Capacities of RO-MOFa and ROMOFf

$\begin{array}{cccccc}\text { MOF } & \begin{array}{c}\text { surface } \\ \text { area } \\ \left(\mathrm{CO}_{2}\right)^{a}\end{array} & \begin{array}{c}\text { water } \\ \text { vapor } \\ \text { uptake }^{b}\end{array} & \begin{array}{c}\text { ethanol } \\ \text { vapor } \\ \text { uptake }^{b}\end{array} & \begin{array}{c}n \text {-pentane } \\ \text { vapor } \\ \text { uptake }^{b}\end{array} & \begin{array}{c}\text { toluene } \\ \text { vapor } \\ \text { uptake }^{b}\end{array} \\ \text { RO-MOFa } & 355 & 3.00 & 0.82 & 0.050 & 0.058 \\ \text { RO-MOFf } & 200 & 2.21 & 3.00 & 1.14 & 1.33\end{array}$

${ }^{a}$ Isotherms were measured at $273 \mathrm{~K}$ and surface areas were calculated using NLDFT analysis. ${ }^{b}$ Isotherms were measured at $298 \mathrm{~K}$ in mmol (vapor) $/ \mathrm{mmol}(\mathrm{MOF})$ at $80 \%$ vapor-saturation pressures.

The significant solvent-uptake capacities of our RO-MOF series in spite of their lower-than-expected gas-sorption surface areas prompted us to examine their ability to uptake vapors of solvents with varying degrees of polarity. To evaluate the vapor sorption capabilities at the two extreme ends of the series, we selected RO-MOFa and RO-MOFf, which show remarkably different vapor-sorption isotherms (Figure 4). Given the nearly

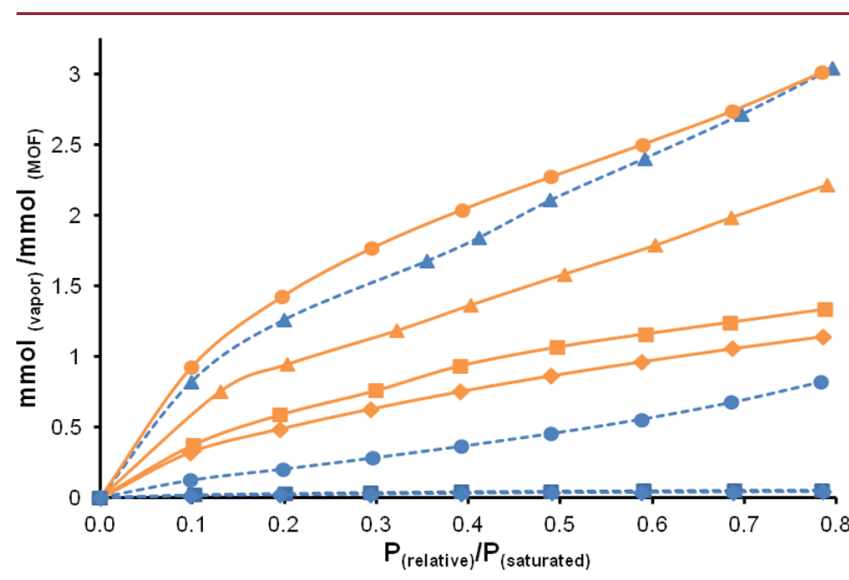

Figure 4. Vapor-sorption isotherms at $298 \mathrm{~K}$ for RO-MOFa (blue dotted line) and RO-MOFf (orange solid line) (triangle = water, circle $=$ ethanol, square $=$ toluene, and diamond $=n$-pentane $)$.

twice-as-large available surface of RO-MOFa, its greater total uptake of water vapor is not surprising $(3.00 \mathrm{mmol} / \mathrm{mmol}$ vs $2.21 \mathrm{mmol} / \mathrm{mmol}$ for RO-MOFf). However, RO-MOFf starkly surpasses RO-MOFa in ethanol uptake $(3.00 \mathrm{mmol} / \mathrm{mmol}$ vs $0.82 \mathrm{mmol} / \mathrm{mmol}$ at $80 \%$ vapor-saturation pressure), which we attributed to a higher degree of hydrophobicity within its cavities. Finally, the uptake of nonpolar molecules such as toluene and $n$-pentane is negligible for RO-MOFa when balanced against uptakes of the same solvents in RO-MOFf (1.33 and $1.14 \mathrm{mmol} / \mathrm{mmol}$ respectively). Considering the kinetic diameters of $n$-pentane $(4.5 \AA),{ }^{41}$ toluene $(5.3 \AA),{ }^{41}$ and ethanol $(4.5 \AA),{ }^{41}$ all of which significantly exceed that of water $(2.6 \AA),{ }^{10}$ a lower absolute uptake of $n$-pentane and toluene is expected even in the highly hydrophobic cavities of RO-MOFf. However, the greater total uptake of the larger ethanol, toluene, and $n$-pentane molecules over the smaller water molecules in RO-MOFf clearly indicates that it is possible to tune the hydrophobicity in the cavities of these MOFs for selective adsorptions of different vapors. On the other hand, given the smaller size of $n$-pentane, size alone does not fully explain the preferential adsorption of toluene over $n$-pentane in RO-MOFf. We hypothesize that such preferential adsorption can be attributed in part to the slightly higher density for toluene ( 9.44 $\mathrm{mmol} / \mathrm{mL}$ vs $8.67 \mathrm{mmol} / \mathrm{mL}$ for $n$-pentane). 
In addition to its ability to selectively adsorb several solvents, RO-MOFa is quite stable to water as observed through repetitive water vapor isotherms. After one week and four cycles, there was no recognizable deviation from the initial water sorption isotherm (Figure S27 in the SI). The good stability of RO-MOFa is further demonstrated in the PXRD pattern measured after the fourth cycle of water vapor sorption, which is in good agreement with the initial PXRD pattern of assynthesized RO-MOFa (see Figure S26 in the SI). In this respect, our RO-MOFs are quite different from other zinccornered MOFs in their ability to remain stable while uptaking a moderate amount of water. ${ }^{28,42}$ We note that several recent reports have described similar strategies for enhancing the water stability of MOFs by appending hydrophobic alkyl groups to the organic struts. ${ }^{27,43-45}$

\section{CONCLUSIONS}

In summary, we have demonstrated the ability to tune the hydrophobicity of the pore environment in a series of isostructural zinc-cornered paddlewheel MOFs by appropriately appending alkyl groups to the bis(pyridyl) struts. In doing so, we can modulate the uptake of guests with a broad range of polarity, with moderate capacities despite low gas-sorptionderived surface areas. This type of pore-environment tuning strategy can potentially be of use in the design of MOF materials capable of environmental sorptive applications while remaining stable to water.

\section{ASSOCIATED CONTENT}

\section{S Supporting Information}

Contents include materials and methods, characterization of ligands, $\mathrm{CO}_{2}$ isotherms, NMR spectra, TGA, sorption measurements and PXRD. This information is available free of charge via the Internet at http://pubs.acs.org.

\section{AUTHOR INFORMATION}

\section{Corresponding Author}

*E-mail: o-farha@northwestern.edu (O.K.F.), j-hupp@ northwestern.edu (J.T.H.), and stn@northwestern.edu (S.T.N.).

\section{Author Contributions}

O.K.F., J.T.H., and S.T.N. conceived the experiments presented herein. M.H.W. and A.A.D. synthesized and characterized all the starting materials and MOFs. A.A.S. performed the singlecrystal diffraction experiments and solved the structures. M.H.W. carried out the gas/vapor sorption measurements of all the MOFs. O.K.F., J.T.H., and S.T.N. supervised the project. M.H.W. wrote the initials draft of the paper with contributions from all the coauthors. M.H.W and S.T.N. finalized the manuscript.

\section{Funding}

Instruments in the Northwestern University Integrated Molecular Structure Education and Research Center (IMSERC) were purchased with grants from NSF-NSEC, NSFMRSEC, Keck Foundation, the State of Illinois, and Northwestern University. Financial support for this work is provided by DTRA (agreement HDTRA1-10-1-0023).

\section{Notes}

The authors declare no competing financial interest.

\section{REFERENCES}

(1) Sumida, K.; Rogow, D. L.; Mason, J. A.; McDonald, T. M.; Bloch, E. D.; Herm, Z. R.; Bae, T.-H.; Long, J. R. Chem. Rev. 2011, 112, 724781.

(2) Farha, O. K.; Yazaydın, A. Ö.; Eryazici, I.; Malliakas, C. D.; Hauser, B. G.; Kanatzidis, M. G.; Nguyen, S. T.; Snurr, R. Q.; Hupp, J. T. Nat. Chem. 2010, 2, 944-948.

(3) Getman, R. B.; Bae, Y.-S.; Wilmer, C. E.; Snurr, R. Q. Chem. Rev. 2011, 112, 703-723.

(4) Farha, O. K.; Eryazici, I.; Jeong, N. C.; Hauser, B. G.; Wilmer, C. E.; Sarjeant, A. A.; Snurr, R. Q.; Nguyen, S. T.; Yazaydın, A. Ö.; Hupp, J. T. J. Am. Chem. Soc. 2012, 134, 15016-15021.

(5) Makal, T. A.; Li, J.-R.; Lu, W.; Zhou, H.-C. Chem. Soc. Rev. 2012, 41, 7761-7779.

(6) Guo, Z.; Wu, H.; Srinivas, G.; Zhou, Y.; Xiang, S.; Chen, Z.; Yang, Y.; Zhou, W.; O’Keeffe, M.; Chen, B. Angew. Chem., Int. Ed. 2011, 50, $3178-3181$

(7) Li, J.-R.; Yu, J.; Lu, W.; Sun, L.-B.; Sculley, J.; Balbuena, P. B.; Zhou, H.-C. Nat. Commun. 2013, 4, 1538.

(8) Debatin, F.; Thomas, A.; Kelling, A.; Hedin, N.; Bacsik, Z.; Senkovska, I.; Kaskel, S.; Junginger, M.; Müller, H.; Schilde, U.; Jäger, C.; Friedrich, A.; Holdt, H.-J. Angew. Chem., Int. Ed. 2010, 49, 12581262.

(9) Wu, H.; Gong, Q.; Olson, D. H.; Li, J. Chem. Rev. 2012, 112, 836-868.

(10) Li, J.-R.; Kuppler, R. J.; Zhou, H.-C. Chem. Soc. Rev. 2009, 38, 1477-1504

(11) Bae, Y.-S.; Lee, C. Y.; Kim, K. C.; Farha, O. K.; Nickias, P.; Hupp, J. T.; Nguyen, S. T.; Snurr, R. Q. Angew. Chem., Int. Ed. 2012, $51,1857-1860$.

(12) Bloch, E. D.; Queen, W. L.; Krishna, R.; Zadrozny, J. M.; Brown, C. M.; Long, J. R. Science 2012, 335, 1606-1610.

(13) Yoon, M.; Srirambalaji, R.; Kim, K. Chem. Rev. 2011, 112, 1196-1231.

(14) Corma, A.; García, H.; Llabrés i Xamena, F. X. Chem. Rev. 2010, $110,4606-4655$.

(15) Lee, J.; Farha, O. K.; Roberts, J.; Scheidt, K. A.; Nguyen, S. T.; Hupp, J. T. Chem. Soc. Rev. 2009, 38, 1450-1459.

(16) Farha, O. K.; Shultz, A. M.; Sarjeant, A. A.; Nguyen, S. T.; Hupp, J. T. J. Am. Chem. Soc. 2011, 133, 5652-5655.

(17) Ma, L.; Abney, C.; Lin, W. Chem. Soc. Rev. 2009, 38, $1248-$ 1256.

(18) Alkordi, M. H.; Liu, Y.; Larsen, R. W.; Eubank, J. F.; Eddaoudi, M. J. Am. Chem. Soc. 2008, 130, 12639-12641.

(19) Yanai, N.; Kitayama, K.; Hijikata, Y.; Sato, H.; Matsuda, R.; Kubota, Y.; Takata, M.; Mizuno, M.; Uemura, T.; Kitagawa, S. Nat. Mater. 2011, 10, 787-793.

(20) Kreno, L. E.; Leong, K.; Farha, O. K.; Allendorf, M.; Van Duyne, R. P.; Hupp, J. T. Chem. Rev. 2011, 112, 1105-1125.

(21) Lee, C. Y.; Farha, O. K.; Hong, B. J.; Sarjeant, A. A.; Nguyen, S. T.; Hupp, J. T. J. Am. Chem. Soc. 2011, 133, 15858-15861.

(22) Kent, C. A.; Liu, D.; Ma, L.; Papanikolas, J. M.; Meyer, T. J.; Lin, W. J. Am. Chem. Soc. 2011, 133, 12940-12943.

(23) Son, H.-J.; Jin, S.; Patwardhan, S.; Wezenberg, S. J.; Jeong, N. C.; So, M.; Wilmer, C. E.; Sarjeant, A. A.; Schatz, G. C.; Snurr, R. Q.; Farha, O. K.; Wiederrecht, G. P.; Hupp, J. T. J. Am. Chem. Soc. 2012, 135, 862-869.

(24) Jin, S.; Son, H.-J.; Farha, O. K.; Wiederrecht, G. P.; Hupp, J. T. J. Am. Chem. Soc. 2013, 135, 955-958.

(25) Kent, C. A.; Mehl, B. P.; Ma, L.; Papanikolas, J. M.; Meyer, T. J.; Lin, W. J. Am. Chem. Soc. 2010, 132, 12767-12769.

(26) Cook, T. R.; Zheng, Y.-R.; Stang, P. J. Chem. Rev. 2012, 113, 734-777.

(27) Nguyen, J. G.; Cohen, S. M. J. Am. Chem. Soc. 2010, 132, 45604561.

(28) Cychosz, K. A.; Matzger, A. J. Langmuir 2010, 26, 1719817202.

(29) Shultz, A. M.; Sarjeant, A. A.; Farha, O. K.; Hupp, J. T.; Nguyen, S. T. J. Am. Chem. Soc. 2011, 133, 13252-13255. 
(30) Lee, C. Y.; Bae, Y.-S.; Jeong, N. C.; Farha, O. K.; Sarjeant, A. A.; Stern, C. L.; Nickias, P.; Snurr, R. Q.; Hupp, J. T.; Nguyen, S. T. J. Am. Chem. Soc. 2011, 133, 5228-5231.

(31) Shultz, A. M.; Farha, O. K.; Adhikari, D.; Sarjeant, A. A.; Hupp, J. T.; Nguyen, S. T. Inorg. Chem. 2011, 50, 3174-3176.

(32) Farha, O. K.; Hupp, J. T. Acc. Chem. Res. 2010, 43, 1166-1175. (33) Farha, O. K.; Malliakas, C. D.; Kanatzidis, M. G.; Hupp, J. T. J. Am. Chem. Soc. 2009, 132, 950-952.

(34) Mulfort, K. L.; Farha, O. K.; Malliakas, C. D.; Kanatzidis, M. G.; Hupp, J. T. Chem.-Eur. J. 2010, 16, 276-281.

(35) Ma, L.; Falkowski, J. M.; Abney, C.; Lin, W. Nat. Chem. 2010, 2, 838-846.

(36) Feldblyum, J. I.; Liu, M.; Gidley, D. W.; Matzger, A. J. J. Am. Chem. Soc. 2011, 133, 18257-18263.

(37) Dybtsev, D. N.; Chun, H.; Kim, K. Angew. Chem., Int. Ed. 2004, 43, 5033-5036.

(38) Hauptvogel, I. M.; Biedermann, R.; Klein, N.; Senkovska, I.; Cadiau, A.; Wallacher, D.; Feyerherm, R.; Kaskel, S. Inorg. Chem. 2011, 50, 8367-8374.

(39) Fernandez, C. A.; Thallapally, P. K.; McGrail, B. P. ChemPhysChem. 2012, 13, 3275-3281.

(40) Culp, J. T.; Smith, M. R.; Bittner, E.; Bockrath, B. J. Am. Chem. Soc. 2008, 130, 12427-12434.

(41) Wu, H.; Gong, Q.; Olson, D. H.; Li, J. Chem. Rev. 2012, 112, $836-868$.

(42) Montoro, C.; Linares, F.; Quartapelle Procopio, E.; Senkovska, I.; Kaskel, S.; Galli, S.; Masciocchi, N.; Barea, E.; Navarro, J. A. R. J. Am. Chem. Soc. 2011, 133, 11888-11891.

(43) Ma, D.; Li, Y.; Li, Z. Chem. Commun. 2011, 47, 7377-7379.

(44) Wu, T.; Shen, L.; Luebbers, M.; Hu, C.; Chen, Q.; Ni, Z.; Masel, R. I. Chem. Commun. 2010, 46, 6120-6122.

(45) Yang, J.; Grzech, A.; Mulder, F. M.; Dingemans, T. J. Chem. Commun. 2011, 47, 5244-5246. 